\title{
"A Most Unprovoked, Unwarrantable, and Dastardly Attack": James Buchanan, Paraguay, and the Water Witch Incident of 1855
}

\section{Gene Allen Smith and Larry Bartlett}

En 1853 la marine américaine a envoyé un petit vapeur pour explorer le fleuve de la Plata en Amérique du Sud. Sans diplomate à bord, le commandant de ce bâtiment s'est trouvé pris au piège dans la politique locale et internationale, ayant pour résultat final en 1855 une attaque paraguayenne contre son navire. Le Président James Buchanan, espérant désamorcer la crise sécessionnelle américaine croissante, a expédié la force navale la plus importante jamais montée par le gouvernement des États-Unis dans les années d'avant-guerre civile; il a voulu unir tous les américains contre un ennemi commun. Malheureusement, l'expédition paraguayenne a failli obtenir un tel nationalisme, et le pays a chuté rapidement vers la guerre civile, et l'épisode du Water Witch s'est trouvée passée sous silence.

Quartermaster Samuel Chaney, aboard the small wooden U.S. steamer Water Witch, did not realize as the morning dawned on 1 February 1855 that he had fewer than nine hours to live. For two years, Chaney and the vessel had been exploring the Paraná River and its tributaries, making astronomical, weather, and magnetic observations while also collecting geological, zoological, botanical, and mineralogical specimens. The scientific expedition also had commercial overtones that rippled the diplomatic waters of the remote region. At approximately two o'clock that afternoon, as the Water Witch navigated the shallow, difficult channels around Caraya Island, the guns of a Paraguayan fort opened fire on the American naval vessel, mortally wounding Chaney and seriously damaging the small ship. The Paraguayan attack represented the final, most extreme act of an escalating series of unfortunate events that ruptured relations between Paraguay and the United States, closed Paraguay to American commerce, brought the two nations to the brink of war, and culminated with the largest U.S. naval expedition sent out during the Antebellum period.

Few remember the voyage of the Water Witch. Spanning the administrations of three U.S. presidents, the events surrounding the expedition present a complex picture. In concept and execution, the expedition embodied several of the Navy's classic peacetime missions. One of a series of such journeys, the Water Witch expedition combined personal ambition, idealism, optimism, hyperbole, and hubris in equal measure. The actions of the 
ship's commander illuminated both the possibilities and the pitfalls of placing naval officers in diplomatic roles. The performance of American diplomats, both before and after the attack, revealed the American diplomatic service at both its best and its worst. Finally, the resolution of the crisis demonstrated the influence domestic politics often exert on foreign policy.

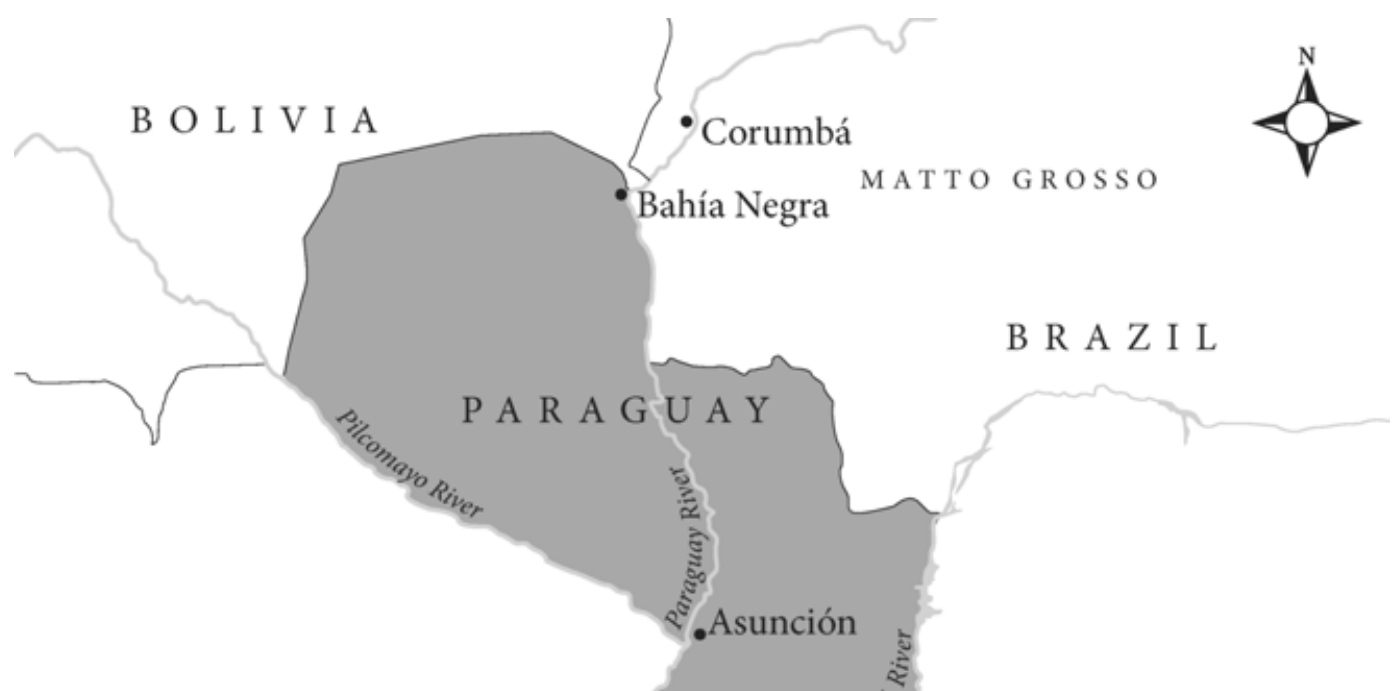

A R G E N T I N A
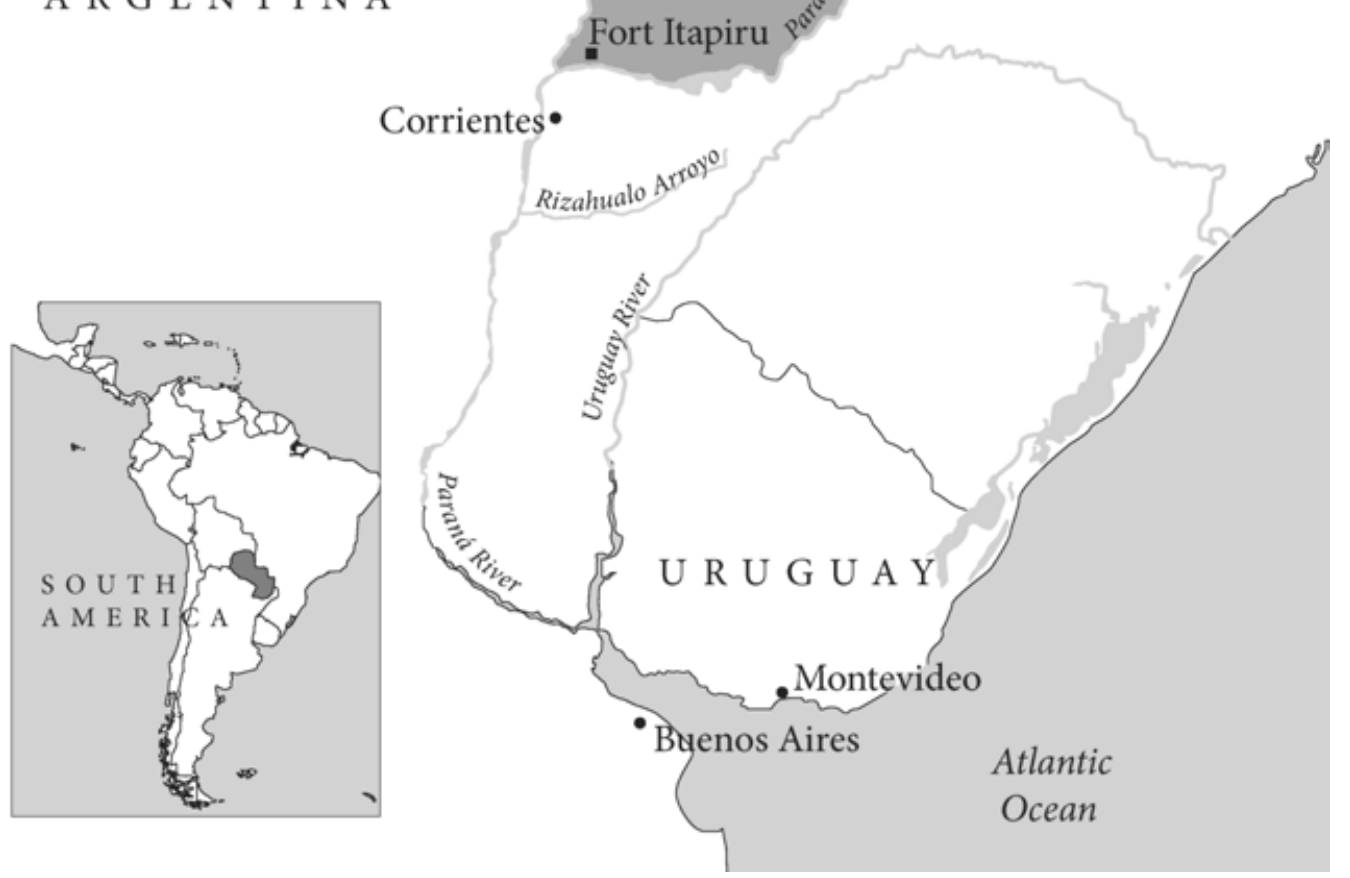

Illustration 1: Paraguay and surrounding area of South America. 
A unique ship in many ways, the Water Witch embodied the experimental spirit that marked the Navy's transition from sail to steam. Some confusion exists as to her exact pedigree. Launched at the Norfolk Navy Yard in 1843, the first U.S. Navy vessel to carry the name Water Witch had an iron hull 100 feet long, a beam of 21 feet and drew nearly nine feet of water when empty. Intended to serve as a water supply vessel for the Norfolk Station, she proved entirely inadequate for that task because her length and draft prevented the steamer from accessing the Great Dismal Swamp Canal, which connected Chesapeake Bay in Virginia to Albermarle Sound in North Carolina, and provided access to the "usually pure" water of Lake Drummond. Hunter's wheels drove the ship, one of three naval vessels so equipped. An experimental propulsion system that proved hopelessly inefficient and slow, Hunter's wheels attempted to reduce the vulnerability of paddle wheels to gunfire by placing them horizontally in casings below the waterline. Naval engineers estimated the work lost by pumping water through the cases at fifty to seventy percent of the applied power. Lengthened in 1845 by thirty feet, refitted with new engines and Loper's screw propellers - another experimental propulsion system - the Water Witch holds the distinction of being the first U.S. Navy vessel with twin screws. Still dissatisfied with her performance, the Navy again rebuilt her in 1847, this time with a single engine driving side paddle wheels. Finally, the Navy condemned the vessel in 1851 , removed her machinery, and used the hull for target practice. Yet in an apparent bit of budgetary obfuscation, her name and engine lived on. The new Water Witch, launched in 1852, had a wooden hull 150 feet long, a 22 -foot beam, and displaced 450 tons at 7 feet 10 inches draft. One other thing had not changed; she again carried an experimental propulsion system. Morgan eccentric feathering paddle wheels, another first for a U.S. naval vessel, provided her main motive force. Feathering paddle wheels improve steaming efficiency by rotating the blades of the paddle wheel, known as "buckets," so they are always perpendicular to the water's surface. With the Morgan wheels, and rigged as a topsail schooner, the new Water Witch demonstrated commendable performance and proved a useful vessel for river exploration. On the La Plata expedition she carried three bronze howitzers as protection against hostile natives. ${ }^{1}$

1 K. Jack Bauer, ed., The New American State Papers: Naval Affairs, 1789-1860, vol. 10, Vessels (Wilmington, DE: Scholarly Resources, Inc., 1981), 103, 276. The Board of Officers' "Report on Steamers" dated 1 March 1853 states that Water Witch was "rebuilt" in 1852; Ronald E. Shaw, Canals for a Nation: The Canal Era in the United States, 1790-1860 (Lexington, KY: The University Press of Kentucky, 1990), 20-21, 117-120; $<$ http://albermarle-nc.com/gates/greatdismal/> 27 May 2009; Frank M. Bennett, The Steam Navy of the United States (1896; repr.,Westport, CT: Greenwood Press, [1972]), 50-53, 141. Bennett refers to the Hunter wheel housings as "drum cases." Bennett has a similar story of "rebuilding" the Franklin using repair funds (over 10 years). Perhaps the most celebrated example of this process was the 1857 "rebuilding" of the frigate Constellation into a sloop. Charles B. Stuart, The Naval and Mail Steamers of the United States (New York, NY: Charles B. Norton, Irving House, 1853), 104; Donald L. Canney, The Old Steam Navy, vol. 1, Frigates, Sloops, and Gunboats, 1815-1885 (Annapolis, MD: Naval Institute Press, 1990), 27, 41-2. Canney refers to the Hunter wheel housings as "casings." "Water Witch," Dictionary of American Naval Fighting Ships, [hereafter, DANFS], Naval Historical Center, $<$ http://www.history.navy.mil/danfs/w3/water-Witch-iii.htm> 14 June 2005. Bennett states 
Her mission, one of a series of such voyages, heralded a new phase in American expansion. By 1848, the United States spanned the North American continent, stretching from the Atlantic to the Pacific. Most Americans accepted the idea that Providence destined the United States to continued growth and that the nation's expansion represented a civilizing process based on moral progress rather than military might. This concept of a "manifest destiny" included two viewpoints. "Continentalists" saw the oceans as barriers behind which the nation could pursue its territorial destiny. Those who expressed a maritime version of Manifest Destiny saw the Atlantic and Pacific as highways; the nation, they argued, would benefit from "international trade, cultural relationships, and scientific investigation." President Millard Fillmore subscribed fully to this maritime view; in his first State of the Union address he insisted that it was "the duty of the government" to promote commerce. He hoped to ensure national economic development by fostering growth in overseas trade. ${ }^{2}$

Lieutenant Charles Wilkes' controversial 1838 South Pacific Exploring Expedition represented one of the earliest of these missions; Navy Department orders directed him to chart the Pacific and the South Seas and "extend the empire of commerce and science." Lieutenant William Herndon's 1851 overland exploration of the Amazon Basin and Commander Cadwallader Ringgold's 1852 expedition to China represent two other attempts to fuse commerce and science. Commodore Matthew C. Perry's 18521854 mission to "open" Japan has undoubtedly garnered the most attention, winning for Perry a spot in the annals of American naval history. The voyage of the Water Witch, commanded by Lieutenant Thomas Jefferson Page, differed little in spirit and purpose from these better-known expeditions, but has remained largely forgotten. ${ }^{3}$

that the rebuilt Water Witch (1845) carried one Loper screw; Canney reports twin screws. Canney appears to be correct. NARS 107-14-13A (National Archives) clearly shows twin screws. In addition, Navy steam engineer Charles Haswell wrote to C.W. Skinner, Chief of the Bureau of Construction that the ship "for a brief period had two of Loper's flat bladed Propellers." Haswell to Skinner, 30 January 1849, published in the Journal of the Franklin Institute vol. XVII (May 1849), 292. Engineer Wm Fallon submitted a report on 9 October 1845 detailing the vessel's performance with the new engines. He also lists two, seven foot, four-bladed props. NARS RG 45, Item \#279. Stuart and Canney both refer to the 1852 vessel as "Water Witch II," while the DANFS refers to the ship as "Water Witch III." Some sources identify her feathering paddle wheels as "Morgan's wheels" - See Wood, n.6, p.8. Thomas Jefferson Page, La Plata, The Argentine Confederation, and Paraguay, (New York, NY: Harper \& Brothers, Publishers, 1859), 26.

2 Geoffrey Sutton Smith, "The Navy before Darwinism: Science, Exploration, and Diplomacy in Antebellum America," American Quarterly vol. 28, no. 1 (Spring, 1976): 43; Millard Fillmore, 2 December 1850, "First Message," in Fred L. Israel, ed., The State of the Union Messages of the Presidents of the United States: vol. I, 1790-1860 (New York, NY: Chelsea House Publishers, 1967), 797; Robert J. Rayback, Millard Fillmore: Biography of a President (Buffalo, NY: Henry Stewart, Incorporated, 1959), 294-319; Elbert B. Smith, The Presidencies of Zachary Taylor and Millard Fillmore (Lawrence, KS: University Press of Kansas, 1988), 220-223.

3 Secretary of the Navy J.K. Paulding to Lt. Charles Wilkes, 11 August 1838. Cited in John P. Harrison, "Science and Politics: Origins and Objectives of Mid-Nineteenth Century 
The Page expedition, in common with all of the other expeditions, grew out of the expansionist attitudes prevalent in mid-nineteenth century America. All of these expeditions had three driving forces: expanding the boundaries of scientific knowledge, encouraging commerce, and enhancing national prestige. In order to obtain funding from an ever-parsimonious Congress, appeals based on national glory and commercial advantage took precedence over those based solely on scientific objectives. This was true even though the Navy adopted a very utilitarian definition of "science"; it sought immediate, practical benefits for itself and U.S. commercial interests in the remote areas of the world. $^{4}$

The La Plata River region of South America encompassed one of these remote areas. To the public, as well as most of the ship's crew, the region seemed obscure, perhaps as mysterious and alluring as China or Africa. Even though ignorant of the region, Americans, pervaded by the spirit of Manifest Destiny, eagerly anticipated opening the unknown region to the Stars and Stripes. The Page expedition would classify the area's natural history, determine its commercial possibilities, expand the bounds of science, and focus American attention on the states of the $\mathrm{La}$ Plata region. Although only a small expedition, the course of events would consume the vessel, embroiling it in a series of international disputes.

Five separate forces combined to initiate the South American expedition. First, in a dramatic shift in 1843, Paraguay initiated

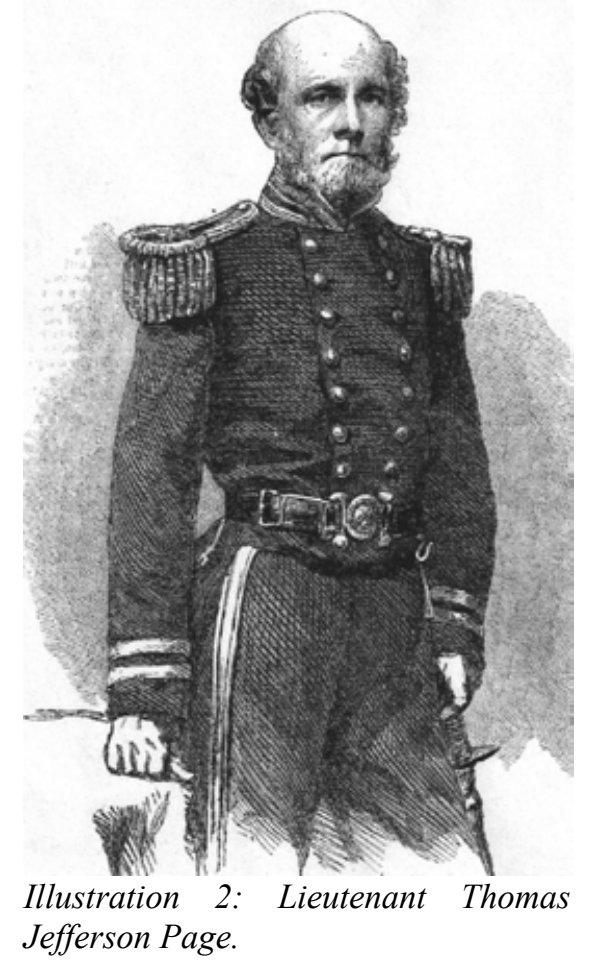

Government Expeditions to Latin America," The Hispanic American Historical Review vol. 35, no. 2 (May 1955), 179-80. Harrison's article provides a detailed examination of the motives behind the mid-nineteenth century expeditions. Other useful discussions can be found in Kenneth J. Hagan's This People's Navy: The Making of American Sea Power (New York: Free Press, 1991), chapters 4 and 5 and Robert W. Love Jr.'s History of the U.S. Navy, 2 vols. (Harrisburg, PA: Stackpole Books, 1992), 1, chapters 13 and 14. Controversy swirled around Wilkes' selection as commander of the expedition. Captain Thomas ap Catesby Jones had been originally chosen. The delay and aggravation caused by Secretary of the Navy Mahlon Dickerson's opposition to the journey eventually forced Jones to ask to be relieved. When no other senior officer would accept the command, Dickerson appointed Wilkes, a lieutenant of but two years' seniority. For a detailed review of the controversy see: Gene A. Smith, Thomas ap Catesby Jones: Commodore of Manifest Destiny (Annapolis, MD: Naval Institute Press, 2000), 71-90 and John H. Schroeder, Shaping a Maritime Empire: The Commercial and Diplomatic Role of the American Navy, 1829-1861 (Westport, CT: Greenwood Press, 1985), 40-70.

4 Smith, "The Navy Before Darwinism," 43-51; Harrison, "Science and Politics," 176-190, 201; Gene A. Smith, “The War that Wasn’t,” California History 66 (June 1987), 105. 
overtures to the United States and other countries for diplomatic recognition and commercial ties. Second, American Edward Anthony Hopkins mounted a determined publicity campaign promoting commercial possibilities in Paraguay. Third, the February 1852 overthrow of Argentine dictator General Juan Manuel de Rosas opened the La Plata estuary and made an American expedition possible. Fourth, President Fillmore earnestly believed that the federal government had a duty to open new markets for U.S. trade. Secretary of the Navy John P. Kennedy's passion for dispatching exploratory expeditions represented the final driver. ${ }^{5}$

South America had experienced considerable turmoil since winning its wars of independence against Spain. In 1814, only three years after independence, Dr. José Gaspar Rodríguez de Francia gained dictatorial power in Paraguay and ruled with an iron fist for the next twenty-six years. He effectively sealed Paraguay off from its neighbors and even stretched a chain across the Paraná River. Francia presided over a brutal regime with a state-controlled economy that provided few opportunities. When he died in 1840 at the age of eighty-four, Carlos Antonio López succeeded him, assuming the title of "Consul," and becoming president four years later. He maintained the same level of control as Francia, but without the repressive brutality, and attempted to implement three foreign policy goals. First, and most importantly, he hoped to gain international recognition of Paraguayan independence as Brazil and Argentina each had tried to incorporate Paraguay within their national territory; second, he hoped to settle the ongoing boundary disputes with Brazil and Argentina; and finally, he wanted to open the country to foreign trade. ${ }^{6}$

Edward Anthony Hopkins proved a tireless ally in López's efforts to open the country to commerce. As a midshipman in the U.S. Navy, Hopkins made two tempestuous cruises to South America. His conduct as a midshipman foreshadowed his later actions as a diplomat. Brought before courts martial three times and dismissed from his squadron, Hopkins resigned from the Navy on 9 June 1845. His ambition and imagination fueled by exposure to exotic South American locales, Hopkins developed a burning desire to explore newly opened Paraguay. Just twenty-two years old when he resigned from the Navy, Hopkins nevertheless convinced President James K. Polk to appoint him special agent to Paraguay. Citing the "industry and zeal" Hopkins had displayed in gathering information on Paraguay and presenting it to the president, Secretary of State James Buchanan nonetheless took note of Hopkins' tender age and offered some advice to his new agent. While assuring Hopkins of the president's confidence in his "ability and discretion," Buchanan cautioned him to control his temper and exercise prudence. Hopkins wasted little time preparing for his new task, departing for Paraguay in late June 1845 and finally arriving at Asunción, Paraguay's capital, on 8 November. His arduous four-and-one-half month journey also included a 1,000-mile overland trek from Rio Grande, Brazil. ${ }^{7}$

$5 \quad$ Harrison, "Science and Politics," 192-3.

6 Philip Raine, Paraguay (New Brunswick, NJ: Scarecrow Press, 1956), 106-24.

7 Navy Department (Washington), Class 2, ZB-Hopkins, Edward A.; Navy Department, Index for Courts Martial and Courts of Inquiry, 1799-1861, nos. 786, 842, and 901; James 
Surprisingly, after his long and difficult journey, Hopkins spent less than two months in Paraguay. During that time, he submitted just one report to the State Department - a 7,000-word missive overflowing with superlatives. He found the local population "extraordinary" and "perfect[ly] content" with their government. President López, he informed Buchanan, enjoyed the "enthusiastic veneration" of the people. Hopkins also described the commercial opportunities in similarly glowing terms. Predicting annual trade in the millions of dollars, Hopkins assured Buchanan that Paraguay "will receive from us every manufactured article our country can send, in the greatest abundance." In return, he claimed, Paraguay offered tobacco, cocoa, rubber, fine leather, tallow, sugar, molasses, rice, dyes, medicinal herbs, precious metals, and gems. ${ }^{8}$

Hopkins' loose interpretation of his instructions prompted his hasty departure; Buchanan had instructed him to evaluate Paraguay's government and recommend whether the United States should recognize López's new regime. The secretary also had cautioned the young agent to keep his official status secret. Yet Hopkins ignored his instructions and dramatically exceeded his authority. Assuming full diplomatic powers, Hopkins immediately promised López that the United States would recognize his government, "fully and explicitly committing the President" and offering the "good offices" of the U.S. government, in the person of himself, in mediating a dispute between Paraguay and the Argentine Confederation. To that end, Hopkins left Asunción on 1 January 1846, bound for Buenos Aires. When his attempt at amateur diplomacy failed, Hopkins chided General Rosas, Argentina's ruler, in a personal letter so insulting that it eventually required a formal U.S. apology. Appalled and astonished by the degree to which Hopkins had "transcended [his] instructions," Buchanan terminated his mission, recalling him to Washington. ${ }^{9}$

Once back in the United States, Hopkins launched a relentless publicity campaign, drafting lengthy letters to the Department of State, penning articles for scientific and business journals, and delivering speeches. In a typical address, delivered before the American Geographical and Statistical Society in January 1852, he extolled the

Buchanan to Edward A. Hopkins, 10 June 1854, William R. Manning, ed., Diplomatic Correspondence of the United States: Inter-American Affairs, 1831-1860, vol. X, The Netherlands, Paraguay, Peru (Washington, DC: Carnegie Endowment for International Peace, 1938), 31-32; Hopkins to Buchanan, 5 August 1845, ibid., 55; Hopkins to Buchanan, 31 [sic] November 1845, ibid., 63.

8 Hopkins to Buchanan, 31 November 1845, ibid., 67.

9 Hopkins to Buchanan, 12 February 1846, ibid., 77; Hopkins to Juan Manuel de Rosas, 19 March 1846. Hopkins' letter is included as a footnote to the letter from Felipe Arana, Argentine Minister of Foreign Affairs to William Brent, U.S. Chargé de Affairs to Buenos Aires; Buchanan to Carlos María de Alvear, Argentine Minister to the United States, 14 August 1846, William R. Manning, ed., Diplomatic Correspondence of the United States: Inter-American Affairs, 1831-1860, vol. I, Argentina (Washington, DC: Carnegie Endowment for International Peace, 1932), 35-36, 343-346; Harris Gaylord Warren, Paraguay: An Informal History (Norman, OK: University of Oklahoma Press, 1949), 190; James Buchanan to Edward A. Hopkins, 10 June 1845, Manning, Diplomatic Correspondence, 10: 29-32; Edward A. Hopkins to James Buchanan, 31 [sic] November 1845, ibid.,67; emphasis in original; Buchanan to Hopkins, 30 March 1846, ibid., 32-34. 
commercial opportunities in Paraguay if only Argentine dictator Rosas were ousted; he also insisted that the time had come for the United States to force an open intercourse and freedom of the river. ${ }^{10}$

Events in Argentina obviated the need for any American action. General Justo José Urquiza, Rosas' second in command, overthrew the Argentine dictator in February 1852. Urquiza and López quickly negotiated a treaty that recognized Paraguay's independence, settled the Argentine-Paraguay boundary issues, and opened the Paraná River to commerce. ${ }^{11}$

Secretary of the Navy Kennedy provided the last ingredient. Assured of the president's support, he indulged his own passion for exploration. He knew the State Department wanted to establish diplomatic relations with Paraguay and that Congress would not oppose an expedition. In addition, he had received a request from a private organization devoted to geographical studies; following Hopkins' speech, the American Geographical and Statistical Society had submitted a memorial, asking the Navy to send an expedition to explore the La Plata region. ${ }^{12}$

The adventurous and ambitious Virginian, Thomas Jefferson Page, longed for promotion. Naval officers rarely received promotions and those beyond lieutenant seemed particularly scarce. Ambitious young officers, condemned by the Navy's small size and rigid seniority system to spend most of their careers as lieutenants, promoted exploratory expeditions as an alternative way to advance their careers. Lieutenant Page had been one of the most vocal advocates calling for the mission to China. Yet by the time Congress approved the expedition, it had grown from a single ship to a small squadron, and Kennedy, convinced that command should go to a more senior officer, chose Cadwallader Ringgold. Offered the post of second in command, the rebuffed Page refused. Kennedy, recognizing his debt to Page, offered the ambitious officer command of the small steamer Water Witch, then being prepared for the La Plata expedition. Serving since 1827, Page, in addition to his excellent ship-handling skills, possessed considerable scientific knowledge, and had literary talents. Although he undoubtedly possessed the technical qualifications to command the Water Witch expedition, later events revealed he lacked essential diplomatic qualifications for an expedition to a tumultuous region. No doubt disappointed at losing the China expedition, Page

10 Edward Hopkins, "Free Navigation of the River Paraná and Its Tributaries," Scientific American vol. VII, no. 19 (24 Jan. 1852), 149. His many writings include: "The Republic of Paraguay; Since the Death of the Dictator Francia," The American Review: A Whig Journal of Politics, Literature, Art and Science, VI (July 1847), 245-260; "Navigation of the Confluents of the Rio de la Plata," The Merchants' Magazine and Commercial Review, XXI (July 1849), 86; "The La Plata and the Parana-Paraguay," DeBow's Review XIV (March 1852), 250; "Free Navigation of the River Paraná and its Tributaries," Hunt's Merchant Magazine and Commercial Review XXVI (February 1852), 147-155; "Memoir on the Geography, History, Productions, and Trade of Paraguay," Bulletin of the American Geographical and Statistical Society (New York, 1852), 1: 14-42.

11 Raine, Paraguay, 125-8.

12 Harrison, "Science and Politics," 195. 
nonetheless accepted his new assignment and ship with enthusiasm and dedication. ${ }^{13}$

The Water Witch sailed from the Washington Navy Yard on 8 February 1853, to determine the practicability of navigation and to discover the courses, extensions, and fish production of the Paraná River and its tributaries. Kennedy directed Page to make astronomical, weather, and magnetic observations and collect geological, zoological, botanical, and mineralogical specimens. The expedition also carried the necessary equipment to record important scenes on daguerreotypes. In addition, Kennedy reminded Page to determine the commercial potential of the region; in essence, the scientific expedition had commercial purposes. When Page arrived off Buenos Aires on 25 May, he found the harbor closed. General Urquiza had placed the city under siege in an unsuccessful attempt to consolidate his power. Prevented from entering the harbor, the Water Witch waited off shore while diplomats from France, England, and the United States mediated a truce. After the cessation of hostilities, Page offered to transport Urquiza and his staff aboard the Water Witch to Urquiza's estancia in the interior provinces. Urquiza would repay the favor many times during the three years of the expedition. $^{14}$

After transporting Urquiza, Page returned to Montevideo, Uruguay, arriving on 2 August. While overhauling and re-supplying his ship, Page had his first encounter with Edward Hopkins. Despite his earlier gaffes as special agent, Hopkins had secured an appointment as U.S. Consul to Paraguay. The rigors of diplomacy, nonetheless, held little allure for Hopkins. He hoped to use his diplomatic position to further his entrepreneurial schemes. While in the United States after his first trip to Paraguay in 1845, Hopkins formed the United States and Paraguay Navigation Company. From López he secured a monopoly on commercial steam traffic on Paraguayan waters. In addition, he planned to build a sawmill and a cigar factory. Competing as he was with a state-controlled economy, Hopkins believed that no private commercial enterprise could succeed unless represented by an official of the U.S. government. Hopkins, on board a foreign vessel flying the American flag, arrived at Montevideo on 19 August. Page immediately objected to such improper usage of the flag. In a reply dripping with arrogance and egotism, Hopkins summarily rejected Page's complaint, setting the tone for the relationship between the two. ${ }^{15}$

Page and the Water Witch finally departed for Paraguay on 31 August, arriving

13 Ibid., 195-6; Thomas Jefferson Page, “Autobiographic Sketch,” Proceedings of the United States Naval Institute vol. 49 (1923), 1661-1691.

14 Harrison," Science and Politics," 196; Robert D. Wood, The Voyage of the Water Witch (Culver City, CA: Labyrinthos, 1985), 6-8, 15. Urquiza, although he had overthrown Rosas, did not have complete control of Argentina. Buenos Aires, the richest Argentine province, had refused to ratify the new constitution and join the Argentine Confederation. Urquiza, unable to compel Buenos Aires' submission, nevertheless, would not agree to a cease fire unless guaranteed safe passage out of Buenos Aires; Water Witch provided that service. On 26 May, Urquiza granted Page permission to explore any of the rivers in the Argentine Confederation. One of his motivations was to reduce the nation's dependence on the maritime trade of Buenos Aires. 
on the first day of October at the Paraguayan capital of Asunción. Page had learned of the complicated border issues in the La Plata region while still at Buenos Aires; at Asunción, he discovered far more serious issues than he had appreciated. In letters to Secretary of the Navy James Dobbins and Secretary of State William Marcy, he warned that the boundary disputes between Paraguay, Brazil, the Argentine Confederation, and Bolivia induced "a most jealous feeling and opposition on the part of Paraguay and Brazil" to exploration and navigation of the Paraná and its tributaries. In addition, López had issued a decree closing the River Paraguay to all foreign ships. Page feared that his expedition might be over before it truly started. ${ }^{16}$

The river system Page hoped to explore waters four countries: Argentina, Paraguay, Brazil, and Bolivia. Entering the lower Paraná at the western end of the La Plata estuary, Page initially sailed northwest up the river. After several hundred miles, the river turns sharply northward until it reaches the southern boundary of Paraguay. At that point, it makes an almost right angle bend to the east. It then gradually curves back to the north until it reaches the point where Paraguay, Brazil, and Argentina meet, at which point it curves northeast into Brazil. The river forms the southeastern border between Paraguay and Argentina. The Paraguay River, with its headwaters in Brazil, flows almost due south, bisecting the Republic of Paraguay and entering the Paraná at the point where that river makes its turn to the east. Bolivia and Brazil disputed ownership of the west bank of the river above Paraguay. The Pilcomayo River flows southeast out of Bolivia and empties into the Paraguay River just below Asunción. The angle formed by the Pilcomayo and Paraguay rivers forms the southwestern border between Paraguay and Argentina. By controlling the lower Paraná, Argentina controls the other three countries' access to the sea. Similarly, Paraguay controls access to the sea by the Matto Grosso, Brazil's southern province. The Brazilians had been trying to gain access to the Paraguay River and the lower Paraná to ensure that their southern provinces had access to the sea, but López steadfastly refused unless Brazil negotiated a treaty of boundary limits. To reinforce his point, López suspended relations in August 1853 and expelled the Brazilian ambassador. ${ }^{17}$

Captain Page had gone ashore for a formal introduction to López in early October. During a second meeting on 10 October, the captain informed López of his intent to institute friendly relations between the United States and Paraguay. Page also hoped, with López's permission, to ascend both the Paraná and Paraguay rivers as far as possible in the pursuit of scientific specimens for further study. López agreed to consider the captain's request. In early November, the Water Witch received permission to explore the rivers, but only to the limit of Paraguayan territory; under no condition could the ship enter Brazilian waters. ${ }^{18}$

16 Thomas Jefferson Page to James C. Dobbin, 1 October 1853, cited in Wood, Voyage, 27; Page to William L. Marcy, 20 October 1853, Manning, Diplomatic Correspondence, 10: 111.

17 John Hoyt Williams, The Rise and Fall of the Paraguayan Republic, 1800-1870 (Austin, TX: Institute of Latin American Studies, 1979), 158.

18 Carlos Antonio López to Thomas Jefferson Page, 5 November 1853, Manning, Diplomatic Correspondence, 10: 114. 
Relieved that his mission could proceed, Page renewed his journey up the Paraguay, reaching Bahía Negra, the northern limit of Paraguayan territory, on 25 November. Page then made a fateful decision. Brazil had given him permission to explore the upper Paraguay River as far as Albuquerque and he decided López had no right to limit his journey. In his opinion, the interests of science compelled him to proceed. By 1 December the Water Witch had anchored off Corumbá, some one hundred and fifty miles into Brazil. At that point, 2000 miles from the ocean and 600 miles farther than any previous vessel had ever gone, the Water Witch sat almost at the center of the South American continent. In an uncharacteristic display of prudence, Page concluded that falling water levels precluded any further exploration. Having proved the river navigable to Corumbá, Page surmised that a smaller vessel might ascend another three hundred miles, perhaps even to Cuiabá, the capital of Matto Grosso. ${ }^{19}$

Page's voyage to Corumbá meant the opening up of the entire Matto Grosso area. Page judged the opening of the interior the greatest achievement of the expedition; the Brazilians appeared similarly enthusiastic. López took a different view. Page, he feared, had set a precedent that Brazil would use to demand passage through Paraguay, and thereafter relations between the two men cooled markedly. Page, hoping to ease the strain between them, prepared a detailed chart of the Paraguay River and presented it to López. $^{20}$

Using Asuncíon as a base, the Water Witch spent most of 1854 charting the Paraná River, the Paraguay River, and their tributaries. To the men of the steamer everything had importance since the ship represented the first mission of its kind to ascend the rivers. Difficulties between Consul Hopkins and the Paraguayan government prematurely ended the adventure in September of that year. Arrogant, egotistical, and presumptuous, Hopkins, in his dual roles as U. S. Consul in Asuncíon and General Agent of the United States and Paraguayan Navigation Company, managed to antagonize almost everyone, including President López. In response, López instituted strict economic policies that made it impossible for Hopkins' company to continue its operations and eventually withdrew his diplomatic exequatur. López then refused to allow Hopkins to leave the country until he surrendered the titles to several disputed properties. Page, based on his own experiences with the consul, believed Hopkins responsible for the difficulties. Nonetheless, he reluctantly concluded that duty compelled him to aid his fellow American. Consequently, on 29 September 1854, Page removed Hopkins and his

19 Page, Paraguay, 118-119. In his memoir of the journey, Page defends his decision to enter Brazil. He argues that López had, in fact, given him permission to enter Brazil since his permission allowed him to sail as far as Bahía Negra "conceded to Bolivia by both Brazil and Paraguay." Once there, he was beyond López's control. This is disingenuous. Page knew the northern border was in dispute. A plain reading of the permission given by López clearly indicates that he considered Bahía Negra to be within Paraguay. Page admits that he placed the "most latitudinous construction" possible on López's concession.

20 Page, Paraguay, 31, 200; Daniel Ammen, The Old Navy and the New (Philadelphia, PA: J. B. Lippincott Company, 1891), 258-9; David F. Long, Gold Braid and Foreign Relations (Annapolis, MD: Naval Institute Press, 1988), 162. 
company's personnel from Paraguay aboard the Water Witch. ${ }^{21}$

López reacted furiously. Not only had Hopkins escaped without relinquishing the disputed titles, but Page had indicated his willingness to use force, if necessary, to facilitate Hopkins's departure. These acts, combined with Page's earlier blatant disregard for the prescribed limit, reinforced López's inherent distrust of foreigners and prompted him to issue an October decree closing Paraguayan waters to all foreign vessels of war. Page's actions also frustrated the exchange of treaty ratifications negotiated in $1853 .^{22}$

López had signed a treaty with the United States in March 1853 and it had been sent to the Senate for ratification. Similar to those between Paraguay and Great Britain, France, and Sardinia, the treaty contained numerous technical errors. Most involved the substitution of the titles "The North American Union" and "The United States of North America" for "The United States of America." The Senate made the necessary corrections and ratified the treaty. Secretary of State William Marcy gave Page the duty of exchanging ratifications of the revised treaty. Banned from Paraguayan waters, Page received the treaty and his instructions in mid-October while his ship lay anchored off Corrientes. No doubt chagrined and apprehensive, Page nevertheless dispatched Lieutenant William Murdaugh to Asunción on a commercial vessel with an English version of the treaty. Paraguayan Foreign Minister José Falcón, standing on a minor diplomatic point, refused to accept the treaty because it did not include a Spanish translation. López's refusal to accept the revised treaty seems a direct consequence of Page's arrogant actions. ${ }^{23}$

The stage for confrontation had been set. Brazilian and Paraguayan relations stood on a tenuous footing. By sailing the Water Witch into Brazil, Page had violated the one restriction López had placed on his activities. In addition, Hopkins had so abused his position as to cause his virtual expulsion from the country. Moreover, Page had facilitated Hopkins's escape from the country, enraging López, who in turn closed Paraguayan

21 Thomas J. Page to William L. Marcy, 17 October 1854, Manning, Diplomatic Correspondence, 10: 143-4.

22 Thomas J. Page to José Falcón, 16 October 1854, ibid., 142-3; Thomas O. Flickema, “The Settlement of the Paraguayan-American Controversy in 1859: A Reappraisal," Americas 25 (July 1968), 52-3.

23 Warren, Paraguay, 194; Thomas Jefferson Page to José Falcón, 16 October 1854, U.S. Congress, Executive Documents, Senate Documents, $35^{\text {th }}$ Congress, $1^{\text {st }}$ Session, No. 11, 40; William L. Marcy to Thomas J. Page, 2 June 1854, Manning, Diplomatic Correspondence, 10: 36; Page to Marcy, 17 October 1854, ibid., 143-144; Page to Marcy, 5 November 1854, ibid., 144-148. John L. Pendleton, the U.S. Chargé to Argentina, had represented the United States in the initial treaty negotiations. López, he reported, had been reluctant to negotiate at all. The representatives from England, France, and Sardinia met with Pendleton and jointly drafted a treaty based on the English proposal. López refused to meet with more than two negotiators; therefore, the English and French ministers spoke for all four parties. All four nations signed identical treaties. The French and English ministers probably did not notice the errors in the title of the United States. Pendleton, in addition, seems to have been careless in his oversight of the process. See John L. Pendleton to U.S. Secretary of State, 4 March 1853, ibid., 104-6. 
waters to foreign vessels. Returning insult for insult, the Paraguayan president refused to exchange ratifications of a treaty with the United States. In January 1855, Page obtained supplies in Buenos Aires, for a second and more detailed voyage up the Paraná River - a journey that brought U.S.-Paraguayan tensions to a climax.

The month of January 1855 saw little more than routine activities for the American sailors aboard the Water Witch. While anchored off Corrientes on 20 January, the men watched Francisco Solano López, the president's son, arrive aboard the Paraguayan steam warship Tacuara. He and Page exchanged cordial greetings, perhaps a sign of improving relations. But Page squandered the chance. The following day, Page and nineteen men departed for the Salado River aboard the small steamer Pilcomayo. He left Lieutenant William Jeffers in command of the Water Witch with orders to explore the upper Paraná. ${ }^{24}$

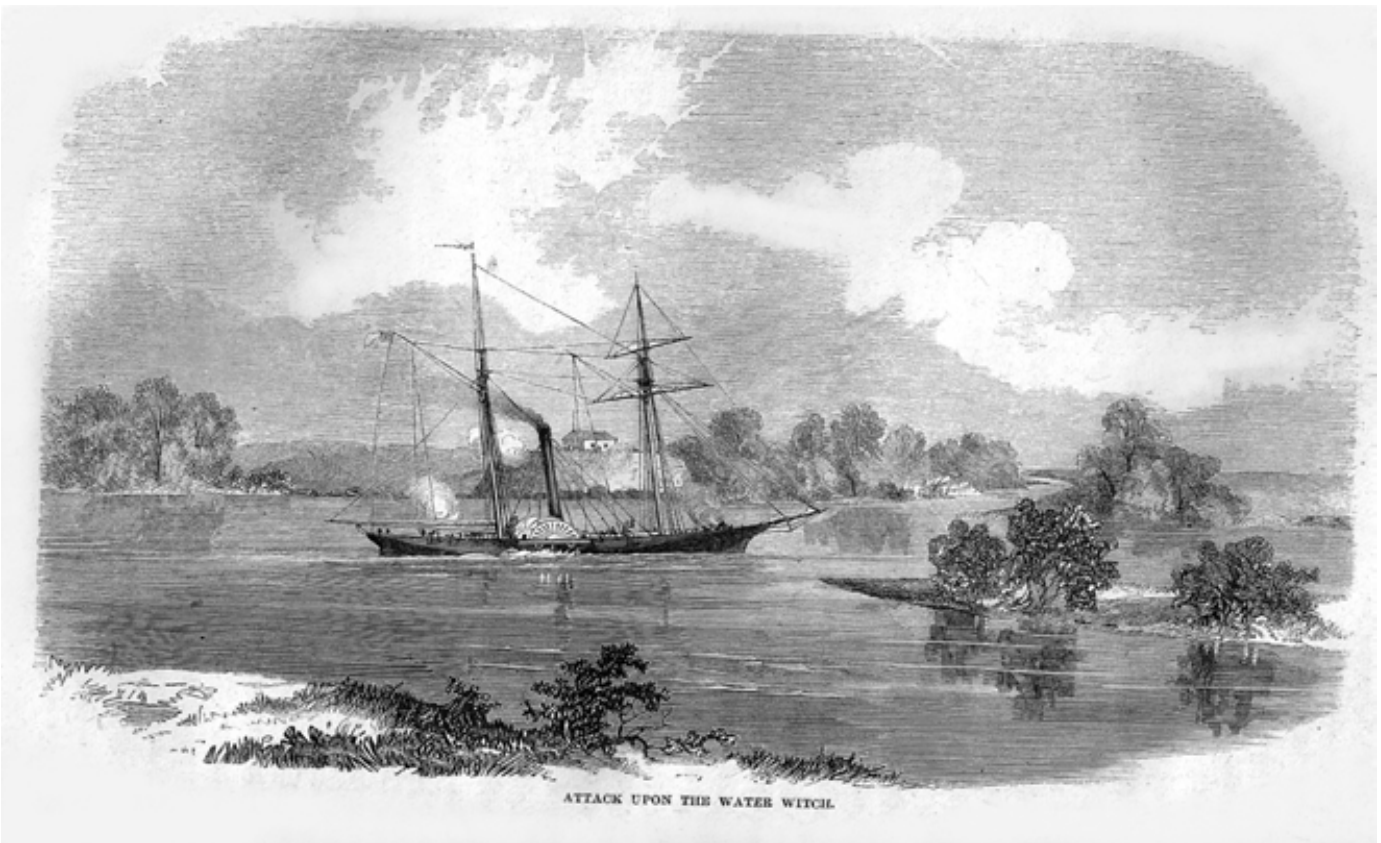

Illustration 3: "Attack upon the Water Witch."

The Water Witch weighed anchor at 6:40 A.M. on 1 February. At about 11:00, the steamer reached the confluence of the Paraná and Paraguay Rivers and turned into the upper Paraná. Four miles upstream, the island of Caraya separated the river into two channels, and about thirty feet above the water, commanding the channel on the Paraguayan side, stood the semi-circular brick fort of Itapiru. Its commander, Vincente Duarte, readied his guns as he watched the vessel approach. At 11:30, about a half mile from the fort, the Water Witch, in attempting to use the channel on the Argentine side, ran aground on a sand bar. For the next forty-five minutes the crew worked to free the ship by

24 Wood, Voyage, 59-60; Thomas Jefferson Page to James C. Dobbins, 5 February 1855, Senate Documents, $35^{\text {th }}$ Congress, $1^{\text {st }}$ Session, No. 11, 42. 


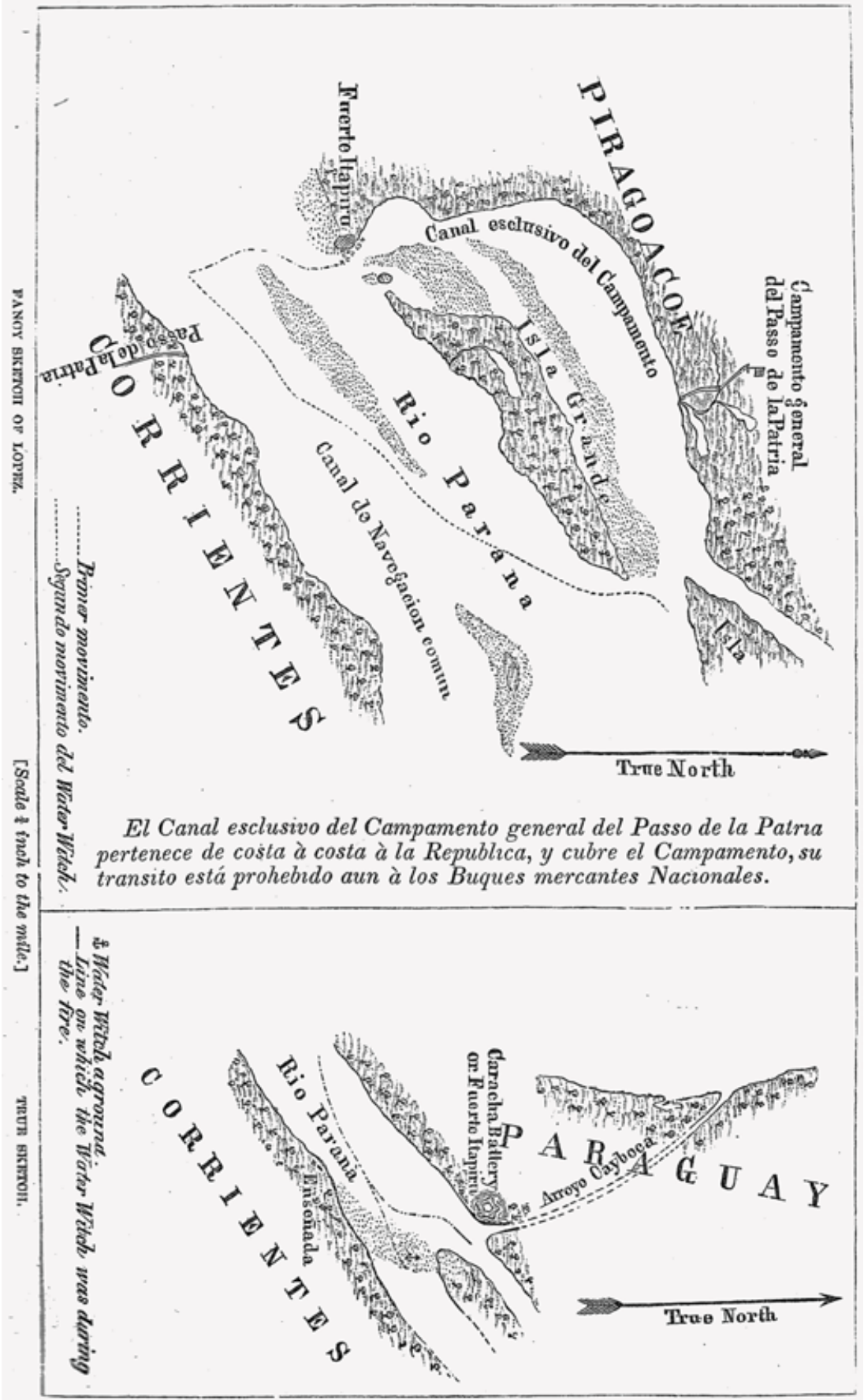

Illustration 4: "Fancy and true sketch" of the incident of 1 February 1855. 
laying out a kedge. After freeing the ship, Jeffers sent his men to dinner. Having observed the Paraguayan preparations at the fort, Jeffers concluded that prudence dictated he prepare as well. Accordingly, he moved the starboard gun to the port side, cleared for action, and ordered forty shrapnel, twelve regular shells, and thirty stand of grape prepared. ${ }^{25}$

At 1:20 in the afternoon, Jeffers weighed anchor again. A Paraguayan canoe, which had been observing the ship, came alongside and a man offered Jeffers a copy, in Spanish, of the October decree prohibiting navigation. Jeffers refused to accept the note on the grounds it was in Spanish, undoubtedly retaliating for López's similar refusal to accept the treaty ratification in October 1854. The ship continued upriver, now using the channel on the Paraguayan side. When three hundred yards from the fort, Jeffers reported, he received a hail from an unidentified man in the fort. Unable to understand the hail, Jeffers continued.

In his report, Jeffers insisted that the fort then fired two blank cartridges followed by a live shot. The Paraguayan shot destroyed the pilot wheel, cut numerous ropes, and mortally wounded helmsman Samuel Chaney. The Water Witch returned fire with her one twenty-four pound and two twelve pound boat howitzers. During the confusion, the pilot deserted his post, hiding behind the engine house, and by the time he could be dragged back on deck the Water Witch had passed the fort and the danger seemed over. Yet the water level had dropped quickly, leaving but one foot more depth than draft. ${ }^{26}$

Jeffers faced a difficult decision. If he went forward, he ran the risk of grounding and losing his ship, since reports credited the fort's garrison with 6,000 men. He had only one other alternative, to return from whence he came, which meant passing the fort again. Jeffers quickly decided to run the gauntlet of Itapiru's guns again, instead of losing without a fight. As he backed downstream, the fort subjected the vessel to a "severe" fire that the Water Witch, almost bows on to the fort, could not return. ${ }^{27}$

The six guns of the fort, their fire "slow, but remarkably well directed," easily out shot Jeffers' three small howitzers. With just twelve shots the fort hulled the ship ten times, destroyed the two boats she towed, and disabled one of the paddle wheels. The gunfire from the steamer, Jeffers claimed, dismounted one of the fort's cannons but otherwise inflicted little damage. ${ }^{28}$

Once out of the fort's range, Jeffers stopped for immediate repairs. While making the needed repairs he considered attacking the Paraguayan steamer Tacuara, which had recently arrived, was firing up her engines, and readying her guns. He reluctantly concluded that the condition of the Water Witch precluded any attempt on the Paraguayan vessel. At 3:00, the steamer weighed anchor and headed down river for Corrientes. The indecisive incident had concluded and four years passed before the two countries finally

25 William Jeffers to Thomas Jefferson Page, 2 February 1855, ibid.

26 Wood, Voyage, 60-1; Jeffers to Page, 2 February 1866, Senate Documents, $35^{\text {th }}$ Congress, $1^{\text {st }}$ Session, No. 11, 43.

27 Ibid., 43-4.

28 Ibid., 44; Wood, Voyage, 61. 
resolved the matter. ${ }^{29}$

The following day Jeffers proceeded down the Paraná to find Page and the Pilcomayo. Enraged by Jeffers' report, Page wanted to destroy the Paraguayan fort. He angrily reported the "most unprovoked, unwarrantable, and dastardly attack" to the secretary of the navy, assuring him that "[with extra guns and men] I shall feel confident of the ability of the 'Water Witch' to avenge the outrage which has been perpetrated on the flag of the United States." Page sailed immediately to Montevideo to inform Commodore William D. Salter, commander of the Brazil squadron, of the incident, fully expecting a forceful response to avenge this violation of American honor. ${ }^{30}$

The orders Page received when departing on the expedition in 1853 warned him that should any trouble occur, he should seek reparation or restitution by persuasive, yet firm, measures, resorting to force only "when no doubt can exist that right and justice are on your side." As far as Page was concerned, a violation had occurred and right and justice were indeed on the American side. The Water Witch had been in the region for two years, he railed, and the peaceful nature of its mission well known. Furthermore, the Paraguayans must have known that with Page and a large portion of the crew absent, the ship presented no possible threat. The canoe that approached the Water Witch had carried neither flag nor uniformed officers, he also complained. Additionally, the steamship could not have stopped in the brief interlude between the fort's warning shots and the live shot. Finally, the American vessel did not return fire until fired upon. The evidence, he concluded, provided overwhelming proof that the attack had been unprovoked, demanding a necessary and justified response. ${ }^{31}$

During the next two months, Page visited the commodore four times but had no success persuading Salter to take action against the Paraguayans. Page first asked to borrow additional guns for the Water Witch. Salter refused. Page then offered to tow the sloop-of-war Germantown up the river to participate in the bombardment of Fort Itapiru. Eschewing gunboat diplomacy, Salter also denied this request. The commodore had decided, after discussions with James A. Peden, U.S. minister to Buenos Aires, that he should await further instructions from Washington. Salter concluded that the United States had three causes of complaint against Paraguay: the exclusion of Hopkins and his

29 Jeffers to Page, 2 February 1855, Senate Documents, 35 $5^{\text {th }}$ Congress, $1^{\text {st }}$ Session, No. 11, 44. The Paraguayan account of the incident presents a somewhat different picture. Following Jeffers' rejection of the written note, the fort fired three unshotted guns as a warning, but the men aboard the steamer "only laughed." Duarte then hailed the steamer three times directing it to stop. Again ignored, Duarte then directed that two more blank cartridges be fired followed by a live shot fired "in front of the bow" but "without touching the hull" of the ship. Following the "shot across the bows," the Water Witch began firing on the fort. Wenceslas Robles to Carlos Antonio López, 1 February 1855, Manning, Diplomatic Correspondence, 10: 150-151; Wood, Voyage, 61.

30 Thomas Jefferson Page to William L. Marcy, 5 February 1855, K. Jack Bauer, ed., The New American State Papers: Naval Affairs, 1789-1860, Vol. 3, Diplomatic Activities (Wilmington, DE: Scholarly Resources, Inc., 1981), 72.

31 Wood, Voyage, 62. 
mercantile company, López's refusal to ratify the Treaty of 1853 , and the unprovoked firing on the Water Witch. The latter also involved the right of navigation on the Paraná River and an indemnity to the family of Samuel Chaney. Although the destruction of Fort Itapiru would bring satisfaction for the outrage against the Water Witch, it would not settle the other issues at hand. Therefore, Salter and Peden decided it would be best for the diplomats in Washington to settle the problem. Their lack of action disgusted Page, who ruefully pointed out that when Brazil had forced the Paraguayans to back down in 1854, "it show[ed] the value of having a force to back up your demands." 32

Meanwhile in Washington, reports of the altercation had arrived

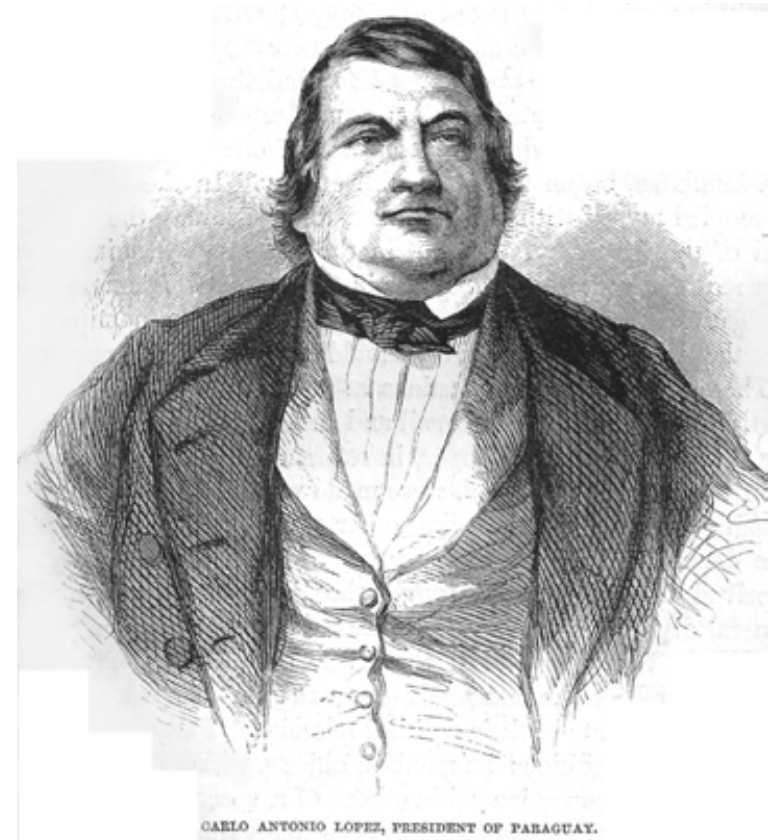

Illustration 5: Carlo Antonio López, President of Paraguay.

from both Paraguayan Foreign Minister José Falcón and Page. Falcón's dispatch to Secretary of State William Marcy claimed the American vessel had violated Paraguayan waters and had been perceived as a threat to Fort Itapiru. His dispatch included a sketch of the river and a plot of the vessel's movements, which he claimed justified the "defensive action" taken by the fort. Page responded by presenting his and Jeffers' official reports along with his map of the river, which defended the actions taken by the Water Witch. Page stressed the well-known scientific nature of the ship's mission and insisted that no deviation had occurred to warrant attack. ${ }^{33}$

Secretary Marcy investigated the incident, finding Hopkins responsible for the tense relations between the two countries and Page and Jeffers directly responsible for the Water Witch incident. Because of his perceptions, the State Department declined to act on the matter. Senator Philip Allen of Rhode Island - the legal home of The United States and Paraguayan Navigation Company-exerted considerable pressure on Hopkins' behalf, prompting Marcy to relent and appoint Richard Fitzpatrick Special Agent to Paraguay in August 1856. Even then, the instructions Fitzpatrick received stressed gaining ratification of the 1853 treaty at the expense of all else. Fitzpatrick's efforts came to naught as López refused to consider the treaty until the United States agreed to

32 Ibid., 63.

33 Thomas Jefferson Page to Mr. Toucy, 4 August 1857, Senate Documents, $35^{\text {th }}$ Congress, $1^{\text {st }}$ Session, no. 11, 51; Page to Dobbins, 5 February 1855, 71; James A. Peden to William Marcy, 29 March 1855, Manning, Diplomatic Correspondence, 1: 578. 
apologize for the Water Witch affair and renounce Hopkins' claim against Paraguay. U.S.Paraguayan relations remained at this impasse until December 1857 when James Buchanan, now president, revived the question in his first annual message to Congress. ${ }^{34}$

Buchanan's presidential address characterized Paraguay's actions as "unjustifiable. . . insulting and arbitrary," demanding redress. The interests of the country demanded satisfaction and he would see justice served. Promising to be "firm but conciliatory," Buchanan opined that Paraguay would more readily agree to America's demands if they were backed by a show of force. At his request, Congress passed a Joint Resolution on 2 June 1858, granting him authorization to use force to obtain redress from the Paraguayan government. It had been thirty-eight months in coming, but Page finally got his desire: America would take forceful action. ${ }^{35}$

In October 1858, a U.S. fleet under the command of Commodore William B. Shubrick, with Page as flag captain, sailed towards Paraguay to settle the question of American honor. The flotilla consisted of nineteen vessels, including eleven steamships, manned by almost 2500 men and mounting more than 200 guns. It represented the largest naval force ever assembled by the United States to that date and the New York Herald hailed it as "one of the most important naval demonstrations that has ever been made by this country." Nevertheless, the presence of Special Commissioner James B. Bowlin revealed that the expedition also had a diplomatic focus and that negotiation would be the first weapon used. ${ }^{36}$

The expedition arrived in the La Plata region in January 1859. Commissioner Bowlin, escorted by a small portion of the fleet (including the Water Witch), sailed up the Paraná River to call on López. Most of the American fleet drew too much water to ascend the river and, thus, posed no direct threat to Paraguayan territory. López understood, nonetheless, the economic damage a blockade, the stated plan should negotiations fail, could cause. Therefore, he adopted a conciliatory attitude.

Bowlin adopted a similar attitude. He offered to have all necessary documents translated into Spanish. Once offered, López waived the requirement. A treaty remained Bowlin's first priority and he interpreted his instructions relative to Hopkins' claim very liberally. Bowlin quickly perceived that the damage claim would be the most difficult issue to resolve. Hopkins sought $\$ 935,000$, but Bowlin had the authority to settle for $\$ 500,000$. Should López refuse to settle, he could suggest an arbitration commission provided Paraguay acknowledge "its liability to the company." By the conclusion of the negotiations, Bowlin had decided that the company's claims had no merit. He convinced López that an arbitration commission would work to Paraguay's advantage, did not

34 Flickema, "Settlement," 55; William Marcy to Richard Fitzpatrick, 5 August 1856, Congress Executive Documents, Senate Documents, $35^{\text {th }}$ Congress, $1^{\text {st }}$ Session, 1857, no. 55-60, 46-50. James Bassett Moore, The Works of James Buchanan, Compromising the Speeches, State Papers, and Private Correspondences (New York, NY: Antiquarian Press, 1960), 12: 242; U.S. Congress, Congress Executive Documents, House Documents, $35^{\text {th }}$ Congress, $1^{\text {st }}$ Session, No. 365, 1-2; Dudley W. Knox, A History of the United States Navy (New York, NY: G.P. Putnam's Sons, 1936), 183. 
include the stipulated acknowledgement of liability, and even offered to testify on Paraguay's behalf. Paraguay agreed to apologize for firing on the Water Witch, pay $\$ 10,000$ to Samuel Chaney's heirs, and sign a new treaty essentially identical to that of 1853. With the demands of honor satisfied, the U.S. government considered the issue settled. It seemed, as Page had predicted, that a show of force would settle the issue. Not surprisingly, the arbitration commission finally ruled in 1860 that Paraguay owed nothing to Hopkins' group. ${ }^{37}$

Why did Buchanan send an expedition of such proportions? Given his prior experience with Hopkins, Buchanan must have entertained doubts about the righteousness of the U.S. position. Additionally, a few minor diplomatic incidents half a world away hardly warranted actions so dramatic, especially since Paraguay was virtually unknown to the United States. Moreover, there had been little, if any, public pressure for action against Paraguay. What little notice the press gave the affair in 1855 generally condemned both Hopkins and Page. Discussing the deteriorating situation in Paraguay, a New York Times editorial blamed the "incapacity and bad faith of our own consul." Opinions remained sharply divided when Buchanan revived the issue in December 1857. The New York Times delivered a sustained and stinging critique of the administration's policies, expressing doubts about the justness of the American position. The paper noted that similar complaints against China had met with a much milder response. The paper again placed the blame on Hopkins and Page and questioned Buchanan's motives, accusing him of "bombast." The journal Advocate of Peace blamed the entire affair on Hopkins and his "exaggerated schemes." Lamenting that the "game is [not] worth the powder," the article insisted that the "commercial value of Paraguay has been overestimated." The Pittsfield Sun and Harper's Weekly defended the administration. The Sun argued that only negotiations backed by force could succeed, while Harper's published a long series of articles complete with illustrations detailing the problems with Paraguay and the progress of the expedition. One article described Paraguay as "uncomparably [sic] the finest country in Latin America" and characterized López as the enemy of civilization. A later article insisted: "We owe it to ourselves and the commerce of the world" to force open Paraguay's rivers. Congressional debates over the president's request also revealed considerable discord. If Buchanan's response seemed wildly disproportionate to the problem, perhaps his true motivation lay outside the international diplomatic situation. ${ }^{38}$

37 Lewis Cass to James B. Bowlin, 6 October 1858, Manning, Diplomatic Correspondence, 10: 44-5; James B. Bowlin to Lewis Cass, 25 January 1859, ibid., 201; David M. Cooney, A Chronology of the U.S. Navy 1775-1965 (New York, NY: Franklin Watts, 1965), 74; New York Herald, 29 September 1858; Warren, Paraguay, 195; Flickema, "Settlement," 65-8. Flickema, "Settlement," 56, n. 30; New York Daily Times, 9 January 1855, 4; The Farmer's Cabinet, 10 May 1855 reprinted a story from the New York Evening Post blaming Page. The New York Daily Times of 19 June 1855 adopted the opposite view, calling the Paraguayans "barbarians" and decrying the "timid policy" of the government. Commodore Salter's performance, the article continued, brought "little credit" to the Navy. "The Paraguay Expedition," Advocate of Peace (March-April 1869), 249-50; "The Paraguay Expedition," New York Times, 12 October 1858, p. 4, col. 2; ibid., 18 November 1858, p. 4, col. 4; "The 
Beyond his official pronouncements, Buchanan remained silent. Nevertheless, Bleeding Kansas, the Lincoln-Douglas debates, personal liberty laws, the emotional issue of slavery, and fear of disunion and war gripped the nation's attention when Buchanan assumed office. Buchanan had stated that a major goal of his presidency would be to defuse the growing sectional crisis. Stymied on the domestic front, Buchanan looked to the foreign policy arena. Paraguay appeared to offer the perfect opportunity for Buchanan to divert attention from the divisive sectional issues of the day. The expedition provided an opportunity to preserve national honor and, in the process, reunite the country against a common foe. Harper's Weekly concurred in a February 1858 article discussing the defense appropriation bills then before Congress. Noting the outstanding difficulties with Mexico, Paraguay, and other Latin American states, the paper observed that "while a foreign war would, under almost any circumstances, be popular with the masses of this country, it would, just at present, possess the singular advantage of diverting attention from the slavery controversy - a consummation which the President must desire to obtain." The New York Times implied as much in a series of articles throughout 1858. An editorial on 5 April suggested that the recent falling out of the French and English offered Buchanan an excellent opportunity to act on his "cherished plan" to acquire Cuba and inaugurate the high-toned foreign policy he had in mind. "Why wait for a settlement of the Kansas Matter," the editorialist asked, "Why not give the public something else to talk and think about besides Kansas and the everlasting Slavery question?"39

Other pundits also weighed in on the subject. The Farmers' Cabinet observed that the naval force about to sail seemed "all out of proportion" to the professed objective. Harper's Weekly parroted the theme and added that it seemed unlikely that the expedition would confine its labors to Paraguay; it would probably "settle all outstanding accounts" with South American nations. The National Era suggested a darker motive. Doubting that "all this circumstance of glorious war has been paraded before the nations for the barren purpose of demanding an apology from the paltry dictator of Paraguay," the article suggested that the expedition's real purpose was to placate Buchanan's Southern supporters who insisted "filibustering for the extension of slavery should be conducted by the government." Others were more charitable. One editorialist, lamenting that Buchanan had "trifled away" two years of his term on "miserable domestic squabbles," urged his readers to watch the developing foreign policy. Buchanan, he asserted, required some bold adventure to salvage his reputation. Arguing that the "political exigencies of his position" had urged Buchanan into "sudden measures of hostility," he concluded "that a foreign difficulty of any moment must scatter all the

Paraguay Expedition," The Pittsfield Sun, 11 November 1858, 2; “The President's Message," Harper's Weekly, 19 December 1857; "War With Paraguay," ibid., 15 May 1858; for the debates see The Congressional Globe, vol. 27, pt. 2, 21 April, 26 April, 4-5 May, 29 May, 1-2 June 1858.

39 James Buchanan to John Y. Mason, 29 December 1856, George Ticknor Curtis, Life of James Buchanan, 2 vols. (New York, NY: Harper \& Brothers, 1883), 2: 1856; Buchanan expressed the same sentiments to newspaper reporters, see the New York Herald, 3 December 1856; "Prospects of a Foreign War," Harper's Weekly, 20 February 1858, 114; New York Times, 5 April 1858, 1. 
hopes of all his opponents. . . and unite not his own party alone, but the people, about his Government, it should be strange indeed if the reflection did not present itself...in a very lovely and patriotic disguise." When the expedition departed, the London Daily News wryly noted; "War is so obvious a means of distracting a nation from its own internal affairs" resorted to by "nearly all governments." "So it may be with Buchanan," the paper suggested. In reality, the expedition did little to divert the nation's attention from the volatile issues that divided the country. ${ }^{40}$

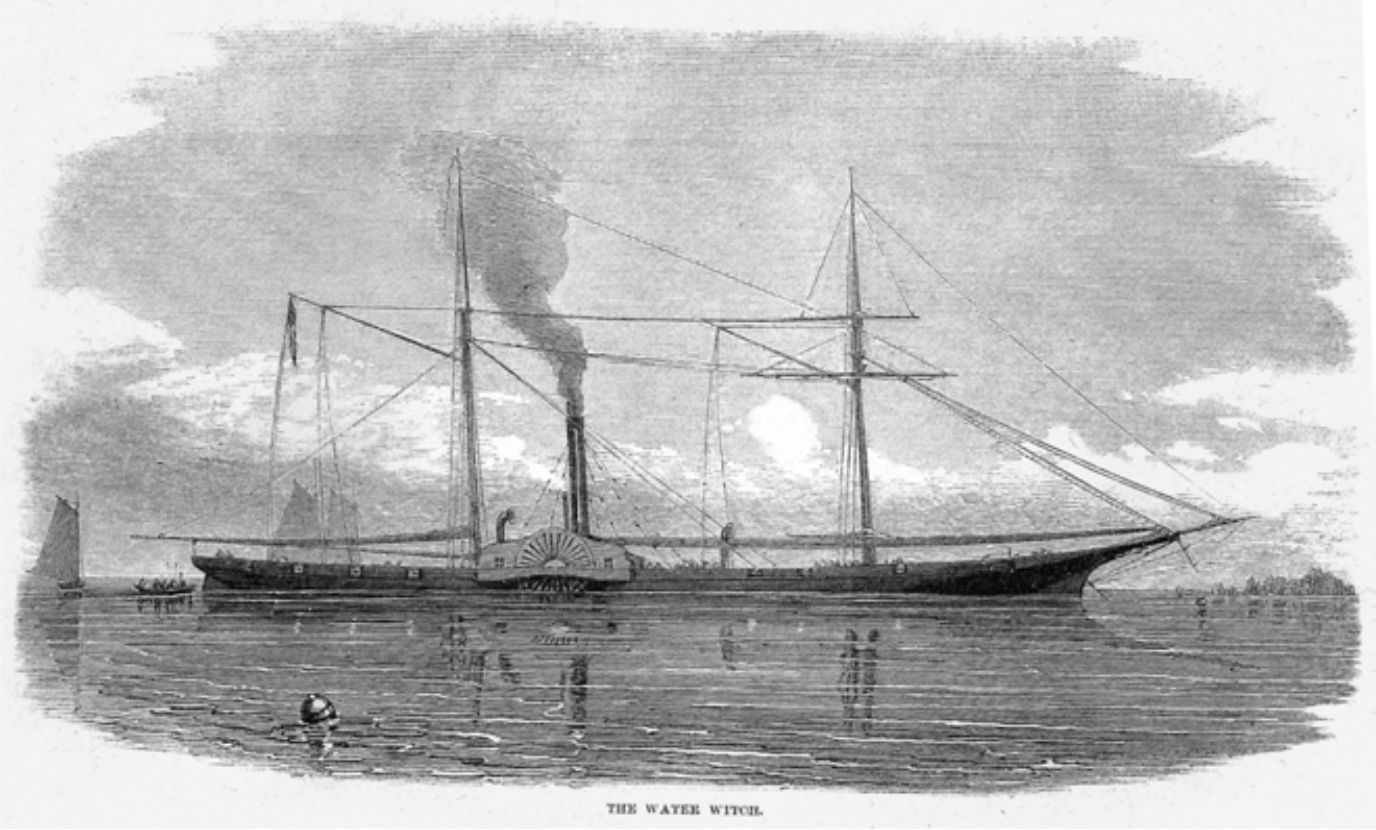

Illustration 6: The Water Witch.

Another common perception concerning this event is that Buchanan wanted to demonstrate "that the United States had the will and the power to enforce the Monroe Doctrine" in the face of growing European economic interests in the area. This interpretation views the punitive expedition as an early example of power projection meant to impress not only Paraguay, but also other South American states and, most importantly, the major European powers. If so, it did not impress the English, one paper dismissively commenting that Great Britain could have fitted out a similar squadron in as many weeks as the United States took months. In this sense, the idea promoted the concept of Manifest Destiny, extended to economic penetration. Industrialization had accelerated in the United States during the 1850s and the country needed to expand its foreign markets. Expanding international trade would bring the U.S. into direct conflict with England and France. Reinterpreting the Monroe Doctrine in this commercial light

40 The Farmers' Cabinet, 13 October 1858, vol. 57, no. 11, 2; "The Paraguay Expedition," Harper's Weekly, 16 October 1858, 669; National Era, 4 November 1858, vol. XII, no. 618, 174; "The Coming Policy," New York Times, 20 November 1858, 4; "Expedition to Paraguay," New York Times, 27 November 1858, p. 2, col. 3. The Times reprinted the story from the London Daily News without comment. 
reinforced its importance to American foreign policy. In fact, the expedition prefigured actions taken by Theodore Roosevelt a half century later; Roosevelt claimed in 1904 that the United States would not interfere with Latin American nations that conducted their affairs with decency, but that "chronic wrongdoing" might require intervention by some civilized power, and the U.S. could not ignore this duty. According to Page and President Buchanan, Paraguay had breached the codes of civilized conduct, and therefore, the United States had a duty to humanity to apply a corrective. ${ }^{41}$

The Water Witch expedition represented but one of a number of exploratory missions dispatched by the United States during the mid-nineteenth century. These missions, imbued with the spirit of Manifest Destiny, had both scientific and commercial overtones. Lieutenant Page and his crew confronted a confused and contentious political situation upon their arrival in the La Plata region. The young nations through which Page hoped to sail had yet to settle their national boundaries. While the local leaders welcomed the benefits increased trade might bring, they simultaneously worried that those benefits might redound to neighboring countries. Success depended on the deft diplomatic skills of the American representatives. Instead, the hubris of Lieutenant Page and Consul Hopkins provoked an international incident. The circumstances surrounding the incident did not produce black and white results and the U.S. government took no immediate action. More pressing domestic concerns overshadowed a minor diplomatic squabble half a world away. President Buchanan hoped to restore national unity by sending a large national fleet to Paraguay to gain redress for alleged wrongs done to American honor. That did not occur and the nation ultimately descended into a brutal civil war, relegating the voyage of the Water Witch, despite all of its achievements, to little more than a footnote in the nation's diplomatic and naval histories.

41 Philip S. Klein, President James Buchanan: A Biography (University Park, PA: Pennsylvania State University Press, 1962), 324; Theodore Roosevelt, State of the Union Address, 6 December 1904, Fred Israel, ed., The State of the Union Messages of the Presidents: 17901966, vol. 2, 1861-1904 (New York, NY: Chelsea House Publishers, 1967), 2134. 